\title{
Forest Resources and Sawmill Structure of Kosovo: State of the Art and Perspectives
}

\section{Šumski resursi i struktura pilana u Republici Kosovo: stanje i perspektiva}

\author{
Professional paper • Stručni rad \\ Received-prispjelo: 31. 7. 2013. \\ Accepted-prihvaćeno: 13. 10. 2014. \\ UDK: $630 * 62 ; 630 * 79 ; 630.832 .1$ \\ doi:10.5552/drind.2014.1343
}

\begin{abstract}
Kosovo, located in the heart of the Balkans, was formerly a part of Yugoslavia. The breakup of Yugoslavia led not only to the creation of new countries and borders; it also had a huge impact on the transportation and availability of raw materials and goods. Kosovo's forest products industry has been greatly affected by the country's current political and legal environment. The creation of new boundaries, combined with trade constraints between Kosovo and some neighboring countries, has changed the amount and type of available wood raw material. Although the forest products industry is a very important part of Kosovo's economy, this change in distribution has had a negative impact on the sawmill structure of the country. To better understand the current state of Kosovo's forest products sector, data was collected through a survey of all sawmills in Kosovo and through information gathered from the Ministry of Agriculture, Forestry and Rural Development of Kosovo. In this paper, the forest resources and sawmill structure of Kosovo are analyzed and the availability of different species of wood in different regions of the country is presented. Based on these findings, recommendations are provided for further development of the forest and sawmill industry.
\end{abstract}

Keywords: forest resources, sawmills, Kosovo

SAŽETAK • Kosovo, koje se nalazi u srcu Balkana, nekad je bilo dio Jugoslavije. Raspad Jugoslavije nije doveo samo do stvaranja novih država i granica; to je također imalo velik utjecaj na transport $i$ dostupnost sirovina $i$ roba. Kosovska industrija drvnih proizvoda uvelike je pod utjecajem trenutačnoga političkog i pravnog okruženja

\footnotetext{
${ }^{1}$ Author is professor at University of Prishtina, Faculty of Applied Sciences, Department of Design and Wood Technology, Republic of Kosovo. ${ }^{2}$ Author is professor at Centro de Estudos Florestais, Instituto Superior de Agronomia, Universidade Técnica de Lisboa, Lisboa, Portugal. ${ }^{3}$ Author is professor at University of Applied Sciences Salzburg, Department of Forest Products Technology and Timber Construction, Kuchl, Austria. ${ }^{4}$ Author is assistant at Department of Forest Products Engineering, Faculty of Forestry, Istanbul University, Istanbul, Turkey. ${ }^{5}$ Author is associate professor at Department of Forest Products Engineering, Faculty of Forestry, Duzce University, Duzce, Turkey. ${ }^{6}$ Author is researcher at National Laboratory for Civil Engineering, Lisbon, Portugal. ${ }^{7}$ Author is researcher at Azorean Biodiversity Group (CITA-A) and Platform for Enhancing Ecological Research \& Sustainability (PEERS), Universidade dos Açores, Angra do Heroísmo, Terceira, Açores, Portugal.

Autor je profesor Sveučilišta u Prištini, Fakultet primijenjenih znanosti, Odjel za dizajn i drvnu tehnologiju, Priština, Republika Kosovo. ${ }^{2}$ Autor i autorica profesori su Tehničkog sveučilišta u Lisabonu, Lisabon, Portugal. ${ }^{3}$ Autor je profesor Sveučilišta primijenjenih znanosti u Salzburgu, Kuchl, Austrija. ${ }^{4}$ Autor je asistent Šumarskog fakulteta Sveučilišta u Istanbulu, Istanbul, Turska. ${ }^{5}$ Autor je izvanredni profesor Šumarskog fakulteta Sveučilišta u Duzceu, Duzce, Turska. ${ }^{6,7}$ Autorica je znanstvenica Nacionalnog laboratorija za građevinarstvo, Lisabon, Portugal i znanstvenica Sveučilišta u Açoresu, Açores, Portugal.
} 
u zemlji. Nastajanje novih granica, $u$ kombinaciji s trgovinskim ograničenjima između Kosova i nekih susjednih zemalja, promijenilo je količinu i vrstu dostupne drvne sirovine. Iako je industrija drvnih proizvoda vrlo važan dio gospodarstva Kosova, ta promjena u distribuciji negativno je utjecala na strukturu pilana u zemlji. Radi boljeg razumijevanja trenutačnog stanja drvnog sektora Kosova, prikupljeni su podaci od svih pilana na Kosovu, i to anketiranjem i dobivanjem informacija od Ministarstva poljoprivrede, šumarstva i ruralnog razvoja Kosova. $U$ radu su analizirani šumski resursi i struktura pilana Kosova te opisana dostupnost različitih vrsta drva u različitim dijelovima zemlje. Na temelju tih nalaza, dane su preporuke za daljnji razvoj drvne industrije i pilanarstva Kosova.

Ključne riječi: šumski resursi, pilane, Kosovo

\section{INTRODUCTION}

1. UVOD

Kosovo, a former part of Yugoslavia and a newly formed independent country, is a landlocked country located in the heart of the Balkan Peninsula. Of the country's total surface area of $10887 \mathrm{~km}^{2}$, approximately 42 $\%$ is covered by forests (Luma and Bajraktari, 2008). Therefore, forestry and forest products industry are important components of the country's economy.

However, the recent political changes regarding new countries and borders have significantly influenced transport and availability of goods and raw materials. Companies formerly conveniently located near abundant raw material sources (e.g. forests) may now be burdened with transport costs and challenging complications due to the need of crossing borders.

Today the wood processing industry in Kosovo only uses roundwood for producing lumber in sawmills and for firewood. The export of logs is negligible (Bajraktari, 2009) and there are no other primary wood working industries (e.g., pulp \& paper or wood based panel industry) located in the country. However, the development of a wood products industry is recognized as an important component for enhancing the economic development of Kosovo. The sawmill structure of Kosovo has not been investigated in detail. This is essential to enable future developments and to support an effective and efficient use of wood resources in Kosovo.

This paper presents the results of a research analysis conducted to understand the situation and structure of forest resources and sawmill industry in Kosovo. The following objectives were defined: 1) to determine the annual roundwood volume felled in the forests of Kosovo in relation to the amounts of timber available in the forests; 2) to describe the sawmill structure in Kosovo; and 3) to analyze the balance between potential supply and processing demand. The understanding of such questions provides the basis for future targets and activities of the Ministry of Agriculture, Forestry and Rural Development of Kosovo (MAFRD), and will encourage efforts to strengthen the country's sawmill industry.

\section{METHODS AND MATERIALS}

\section{METODE I MATERIJALI}

\subsection{Wood resources from Kosovo forests}

2.1. Drvna sirovina iz kosovskih šuma

Data related to Kosovo's current wood resources and use of roundwood were collected using the 2003 data of a forest inventory compiled by the Food and Agriculture Organization of the United Nations (FAO, 2003). This report indicates that Kosovo's total forest area is approximately 460800 ha. Of the total forest area, approximately 353400 ha (77\% of the total) are broadleaf forests, 19200 ha $(4 \%)$ are dominated by softwoods, and 88200 ha (19\%) were not investigated due to risks associated with military mines. Additional information obtained from a 2008 project conducted by the United States Agency for International Development (USAID), which also addressed forest resources in Kosovo, was used and annual roundwood fellings were estimated (Kaciu et al., 2008).

The annual felling allowance for each wood species in Kosovo is currently set by the Ministry of Agriculture, Forestry and Rural Development (MAFRD). The felling allowance for 2008 was divided by three main groups of wood species: beech (Fagus sylvatica subsp. moesiaca) with $436000 \mathrm{~m}^{3}$; oaks (Quercus spp.) with $341000 \mathrm{~m}^{3}$; and softwoods (Abies alba, Picea abies, Pinus heldreichii, etc.,) with $123000 \mathrm{~m}^{3}$ (MAFRD, 2008). The total allowance for each species is divided between all the districts of Kosovo.

The potential log resource is defined as the amount of logs with a small end diameter above $7 \mathrm{~cm}$ and was calculated according to the felling allowance and the MAFRD data (Bajraktari et al., 2009). The quality of the logs was not considered in this analysis.

\subsection{The structure of Kosovo sawmill industries}

2.2. Struktura pilanske industrije Kosova

According to a study conducted by the Ministry of Trade and Industry of Kosovo (MTI, 2008), the amount of lumber imported into Kosovo is much higher than the amount exported. In 2006, the difference amounted to $223797 \mathrm{~m}^{3}$. The study also indicated that Kosovo's forests were capable of supplying a log volume of $693000 \mathrm{~m}$, which is much higher than currently felled and cut in sawmills. However, specific information about the sawmill structure was not given.

To gather additional data about the structure of sawmill industries, the following information for all the 143 registered sawmills (Ukaj and Abazi, 2009) in Kosovo was collected via telephone interviews:

- the cutting technology used (in Kosovo only frame saws and band saws are in use)

- the annual log breakdown divided into the above mentioned groups of wood species.

The results were analyzed separately for 30 districts of Kosovo. 


\subsection{Comparing wood resources and sawmill} demand

2.3. Usporedba resursa drvne sirovine i zahtjeva pilana

The amount of available roundwood resources and the amount of wood demanded by various sawmills were compared for each district. The difference between total log supply and demand was calculated for the three groups of wood species. This calculation was used to determine the regions with oversupply and undersupply and a map highlighting this balance was created.

The information obtained will be used to describe the current state of the sawmill industry in Kosovo and to determine future opportunities for establishing or reorienting manufacturing enterprises to optimally utilize the available roundwood resources.

\section{RESULTS}

\section{REZULTATI}

\subsection{Wood resources per district and wood} species

3.1. Resursi drvne sirovine prema distriktu i vrsti drva

Figure 1 shows the geographical distribution of availability of wood resources per district and by groups of species in Kosovo, as given by the felling allowances (MAFRD, 2008).
Overall, there is a low quantity of wood available for felling in the central region of Kosovo (mainly in the districts of Obiliq, Fushe Kosove and Gllogove).

Beech wood resources are widely available in all the remaining districts of Kosovo, except for the ones located in the southern region where there is a smaller amount available for felling.

Although oaks are common wood species in the country, the data show that the southern and western regions have a significantly lower quantity than the northern and eastern regions.

As regards the softwoods available for felling, they are only abundant in high quantities in the western part of the country (the districts of Gjakove, Peje and Istogu), while in the east and especially in the southeast of Kosovo there are almost no softwoods allowed for felling (Figure 1).

\subsection{Sawmill structure}

\subsection{Struktura pilana}

Out of a total of 143 sawmills in Kosovo, 106 sawmills work with a frame saw and 37 with a band saw (74 $\%$ and $26 \%$, respectively). Figure 2 shows the breakdown per district for the two technologies in relation to the amount of processed wood. It can be seen that operations using frame saws are concentrated in the western districts (Deqan, Peje and Istogu), while those using
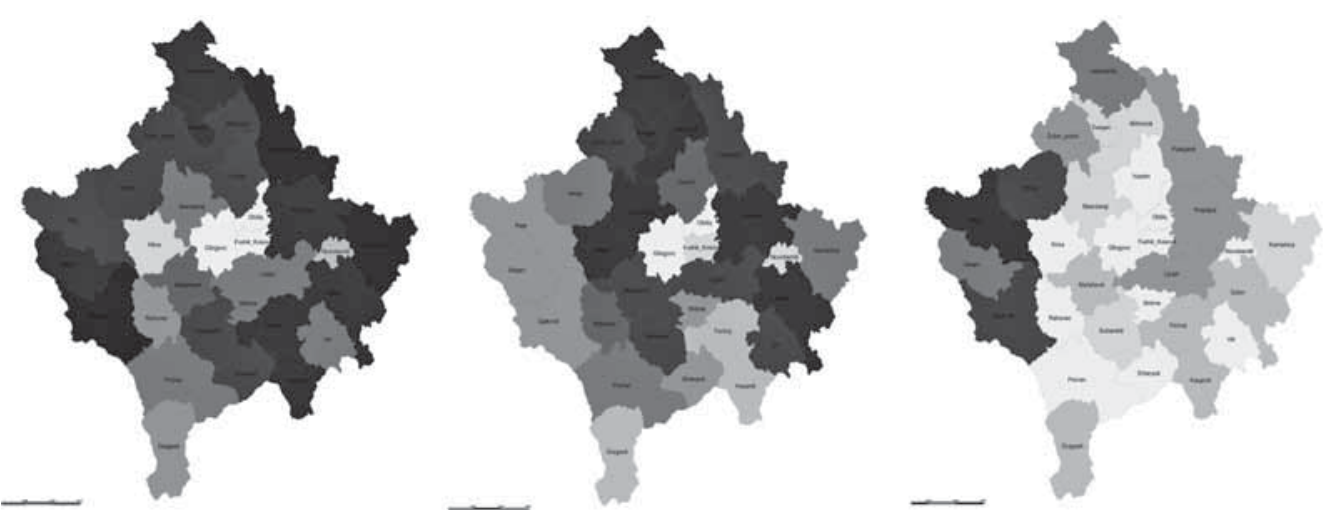

quantity [m?

Figure 1 Allocation of beech (left), oak (middle) and softwood (right) in Kosovo (light green - low quantity, dark green high quantity)

Slika 1. Alokacija bukve (lijevo), hrasta (sredina) i mekih vrsta drva (desno) na Kosovu (svjetlozeleno - mala količina, tamnozeleno - velika količina)
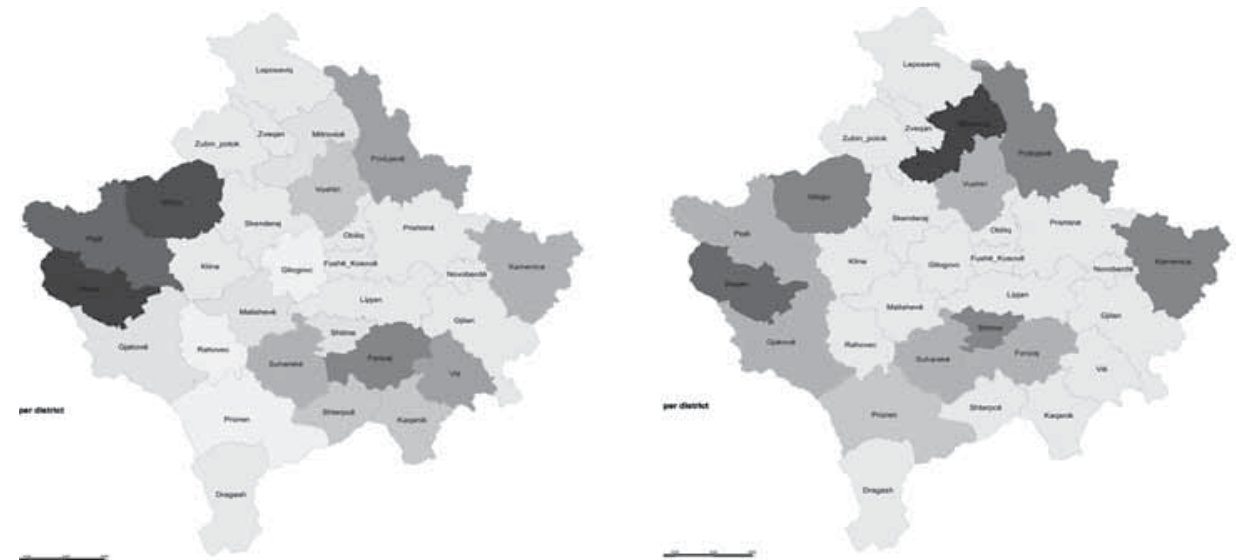

quantity $\left[\mathrm{m}^{3}\right]$

Figure 2 Timber cut with frame saw (left) and band saw (right) in Kosovo

Slika 2. Raspiljivanje trupaca pilama jarmačama (lijevo) i tračnim pilama (desno) na Kosovu 

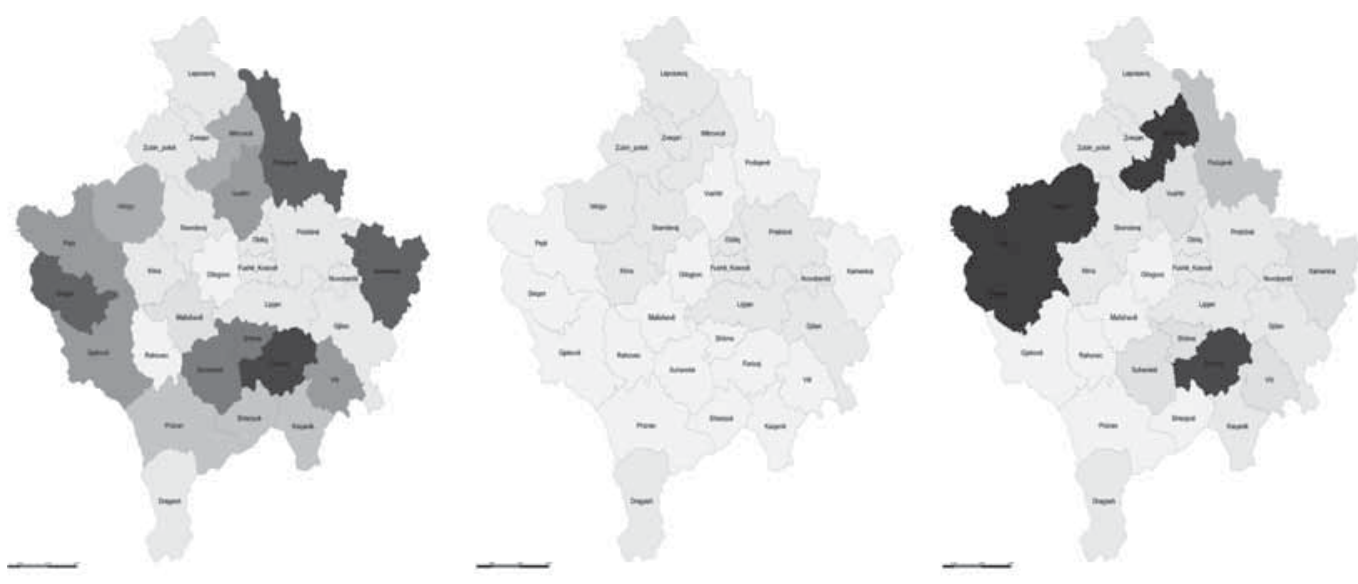

quantity [ $\left.\mathrm{m}^{3}\right]$

Figure 3 Breakdown of beech (left), oak (middle) and softwood (right) in sawmills in Kosovo

Slika 3. Raspodjela bukovih trupaca (lijevo), hrastovih trupaca (sredina) i trupaca mekih vrsta drva (desno) u pilanama na Kosovu
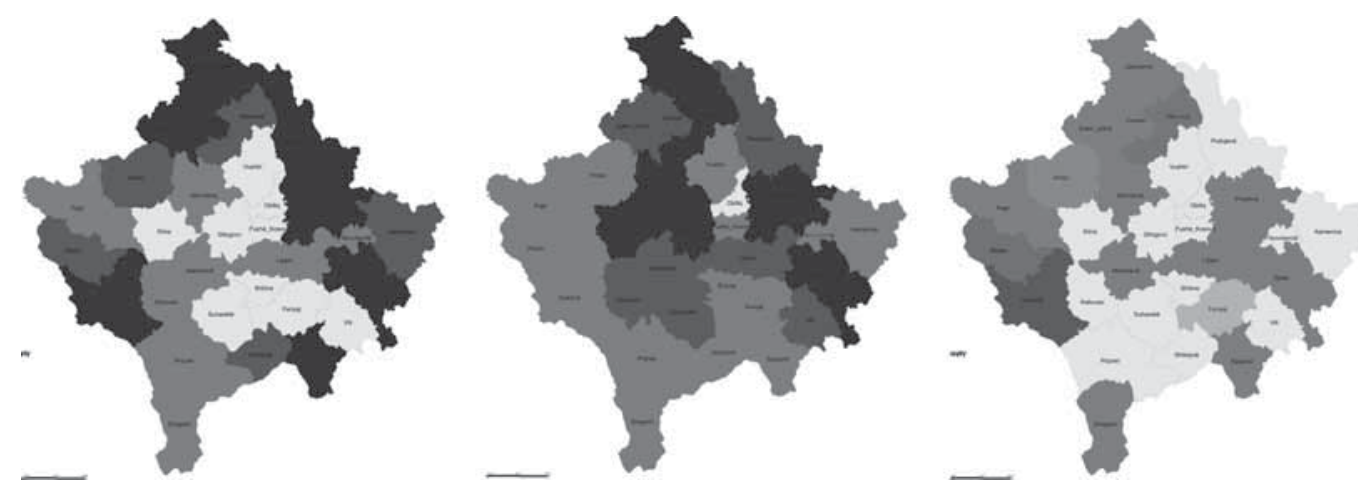

quantity $\left[\mathrm{m}^{3}\right]$

Figure 4 Oversupply and undersupply of beech (left), oak (middle) and softwood (right) in Kosovo (blue oversupply, red undersupply)

Slika 4. Prevelika i premala ponuda bukovih trupaca (lijevo), hrastovih trupaca (desno) i trupaca mekih vrsta drva (desno) na Kosovu (plavo - prevelika ponuda, crveno - premala ponuda)

band saws are concentrated in the eastern districts with a very high concentration in Mitrovice. Most log processing takes place in the regions located in the east and west of Kosovo, with significant amounts being processed in the districts of Ferizaj, Shtime and Suhareke (amounting to more than $21000 \mathrm{~m}^{3}$ ).

As regards the breakdown of processed timber by species, the data is shown in Figure 3. It can be seen that for beech and oaks, processing is distributed throughout the country without a high concentration in one specific region. This is different for softwood sawmilling and it seems that the sawmills in the western region, including the districts of Peje, Istogu, Deqan and Mitrovice, have a focus on cutting softwoods. The frame saw mills are also mainly concentrated in the western region in the districts of Peje, Istogu and Deqan. This indicates that these frame saw mills have specialized in cutting softwoods, while the sawmills in Mitrovice mainly use band saws to cut softwoods.

\subsection{Comparison of supply and demand}

\subsection{Usporedba ponude i potražnje}

The balance between the potential wood supply (allowable cuts, Figure 1) and the industrial wood demand (sawmill processed wood, Figure 3) was calculated and the undersupply and oversupply of wood re- sources was determined for each district and species (Figure 4).

The supply of beech and oak sawlogs sufficiently meets the demands of sawmills in all of Kosovo's districts. However, the situation is different for softwoods. There is a need for additional softwood supply especially in the districts of Deqan, Mitrovice and Istogu. In total, there is a softwood undersupply of approximately $15000 \mathrm{~m}^{3}$ in Kosovo. This negative balance is met by imports, and currently softwoods are predominately imported from Montenegro.

In former times, softwood was also imported from Serbia with a large quantity going to the district of Mitrovice. However, softwood imports from Serbia have not been available since 1999 due to the border closing for log imports. Log imports are possible from Montenegro and Albania, and therefore the districts near these countries (Deqan and Istogu) have a higher share in the softwood supply.

\section{DISCUSSION AND CONCLUSIONS 4. RASPRAVA I ZAKLJUČAK}

It is evident from the results that one of the country's major forest management tasks should be the ef- 
ficient management of softwood resources to meet the continuous demand of the sawmill industry.

The softwood sawmill industry of Kosovo has drastically changed due to the breakup of Yugoslavia. Sawmills located in districts like Mitrovice, that were near large supplies of softwoods, are no longer optimally located. On the contrary, numerous sawmills were established in the last 10 years in the districts of Deqan and Istogu, showing that the sawmill industry is reacting to the new resource location. The efficient management of this resource may, therefore, support the development of a thriving wood products industry and enhance the economy of Kosovo. At the forest level, and given the deficit of national softwoods for the processing industry, attention should be focused on development plans and silvicultural management options for an increased softwood production.

This study also shows that sawmills processing beech and oaks are located over the country and that there is a potential supply surplus allowing the increase of production of sawn products from beech and oaks. However such a production increase only makes sense if two factors converge: i) a market need for the sawn wood; and ii) an effective supply of quality logs. The present study did not investigate the quality of the potential available logs and further research is needed in this area. In fact developing log grading rules and increasing the availability of high quality logs are two of the main objectives of MAFRD that has already started to increase thinning in Kosovo's forests in order to accomplish these objectives. A careful and cooperative approach between the wood products market, wood industry and forest services is certainly a key issue for a balanced forest-to-consumer chain.

The lack of wood-fiber based industries (e.g., wood-based panel production or pulp industries) is also an important topic for the value optimization of the wood chain that requires the cooperation of the forest raw-material supplier (MAFRD) and the forest products industry. Currently, by-products like wood shavings or sawdust do not have a market and their use as an energy resource is virtually non-existent. The creation of markets for by-products could further enhance the economic development of the country and a full resource valorization. Awareness of emerging uses, such as those based on biorefinery approaches to value residual biomass, should also be scrutinized. A recent example is the potential valorization of Quercus cerris bark (an oak species of Kosovo) through its cork component to be used as insulation material in the form of expanded cork agglomerates in the construction industry (Sen et al., 2012).

An important topic not covered in this research is the impact of the use of firewood in Kosovo. This paper only focused on sawmills because of the complexity of obtaining information on firewood (e.g. illegal firewood cutting or missing census). However, understanding the amount of the use of firewood in Kosovo is also an important element for improving the whole forest sector and will be a focus of this research group in the future.
In conclusion, this paper discusses the current state of wood supply and demand of Kosovo's sawmill industry and represents a basis for implementation of policies and activities in this field. Numerous research and policy questions remain to be answered, but our belief is that solving them stepwise and with an integrated sectorial approach will be crucial for successfully reconstructing and developing Kosovo's economy.

\section{Acknowledgements - Zahvala}

This research was supported by the Agency of European Integration and Economic Development.

\section{REFERENCES}

5. LITERATURA

1. Bajraktari, A., 2009: Forest Resources and Future Forestry Strategic Development. Report to the Ministry of Agriculture, Forestry and Rural Development. May 2009. Prishtina, Republic of Kosovo.

2. Bajraktari, A.; Abazi, H.; Luma, M., 2009: Kosovo's Forests, Report to the Ministry for Agriculture, Forestry and Rural Development. September 2009. Prishtina, Republic of Kosovo.

3. FAO 2003: Kosovo's Forests Inventory Report. Food and Agriculture Organization of the United Nations. April 2003. Prishtina, Republic of Kosovo.

4. Kaciu, S.; Jahanica, V.; Aliu, F., 2008: Forest Industry Challenges of Development and Balanced Use Kosovo Cluster and Business Support Project. United States Agency for International Development.

5. Luma, M.; Bajraktari, A., 2008: Kosova's Forestry Statistics. Report to the Ministry of Agriculture, Forestry and Rural Development. September 2008. Prishtina, Republic of Kosovo.

6. MAFRD (2008). Report on the register of the Economic Units in Kosovo. September 2008. Ministry for Agriculture, Forestry and Rural Development. Department of Forestry. September 2008. Prishtina, Republic of Kosovo.

7. Ministry of Trade and Industry of Kosovo EICIKS, Investment Promotion Agency of Kosovo 2008: Primary Wood Production and Wood Processing Industry. June 2008. Prishtina, Republic of Kosovo.

8. Sen, A.; Miranda, I.; Pereira, H., 2012: Temperature-induced structural and chemical changes in cork from Quercus cerris. Ind. Crops Prod. 37: 508-513 http://dx. doi.org/10.1016/j.indcrop.2011.07.028.

9. Ukaj, H.; Abazi, H., 2009: Report on the Register of the Sawmills in Kosovo. Ministry of Agriculture, Forestry and Rural Development. Department of Forestry. Unit of Inspection. August 2009. Prishtina, Republic of Kosovo.

\section{Corresponding address:}

Prof. Agron BAJRAKTARI, Ph. D.

University of Prishtina

Faculty of Applied Sciences

Department of Design and Wood Technology

Deshmorete Kombit, Ferizaj,

REPUBLIC OF KOSOVO

e-mail: agron.bajraktari@uni-pr.edu 